\title{
SELECTION AGAINST THE MELANIC MORPHS OF ADALIA BIPUNCTATA (TWO-SPOT LADYBIRD): A REVIEW AND SOME NEW DATA
}

\author{
JOHN MUGGLETON \\ Department of Genetics, University of Nottingham, Nottingham NG7 2RD
}

Received: 17.vi.77

\begin{abstract}
SUMmary
Work on the nature of the factors selecting against the melanic morphs of Adalia bipunctata is reviewed.

New data are presented showing that there is normally one generation per year in Great Britain and that the cyclical changes in morph frequency observed in Berlin may not occur in Great Britain.

The roles of migration and selective predation in limiting the spread of the melanic morphs are discussed and evidence is presented to show that predation by birds on ladybirds occurs more frequently than previously supposed.

In conclusion it is proposed that the melanic frequency of a population is the result of the interaction of a number of factors whose importance varies from locality to locality.
\end{abstract}

\section{INTRODUCTION}

THE polymorphism found in Adalia bipunctata L. (two-spot ladybird) has been studied for many years and it is established that some populations contain a large proportion of melanic morphs. There are several melanic and non-melanic morphs and these are under the control of a number of alleles at a single locus with the melanic morphs being dominant to the non-melanics (Lusis, 1928, 1932). The melanic morphs have a black background coloration with red spots in contrast to the non-melanics which are red with black spots. Intermediates are rare but when they do occur can be classified by reference to the forms depicted by Lusis (1932). The nature of the factors maintaining this polymorphism in Great Britain has been the subject of recent discussion (Creed, 1971 a, 1975; Muggleton, Lonsdale and Benham, 1975) and for the most part this discussion has concentrated on those factors that advantage the melanic morphs. Yet, in spite of the fact melanics are dominant and have been present since at least 1696 (Hammond, 1975), populations with high frequencies of melanics are uncommon and throughout most of the range of this circumboreal species high frequencies of typicals are found. Indeed, high melanic frequencies are characteristic only of populations from the climatic extremes of the species range in Europe and Asia (i.e. from north-west Europe, southern Europe and central Asia). Fig. 1 shows the frequency of the melanic morphs in all samples for which there are published data.

From the generally low frequencies of melanics in most populations it is clear that in most localities the melanic morphs must be at a considerable disadvantage. Recent evidence from urban areas, where high melanic 
frequencies occur as a result of smoke in the atmosphere, shows that when the smoke levels are reduced there is a rapid decrease in melanic frequency (Creed, 1971b; Bishop, Cook and Muggleton, 1978a) which must be the

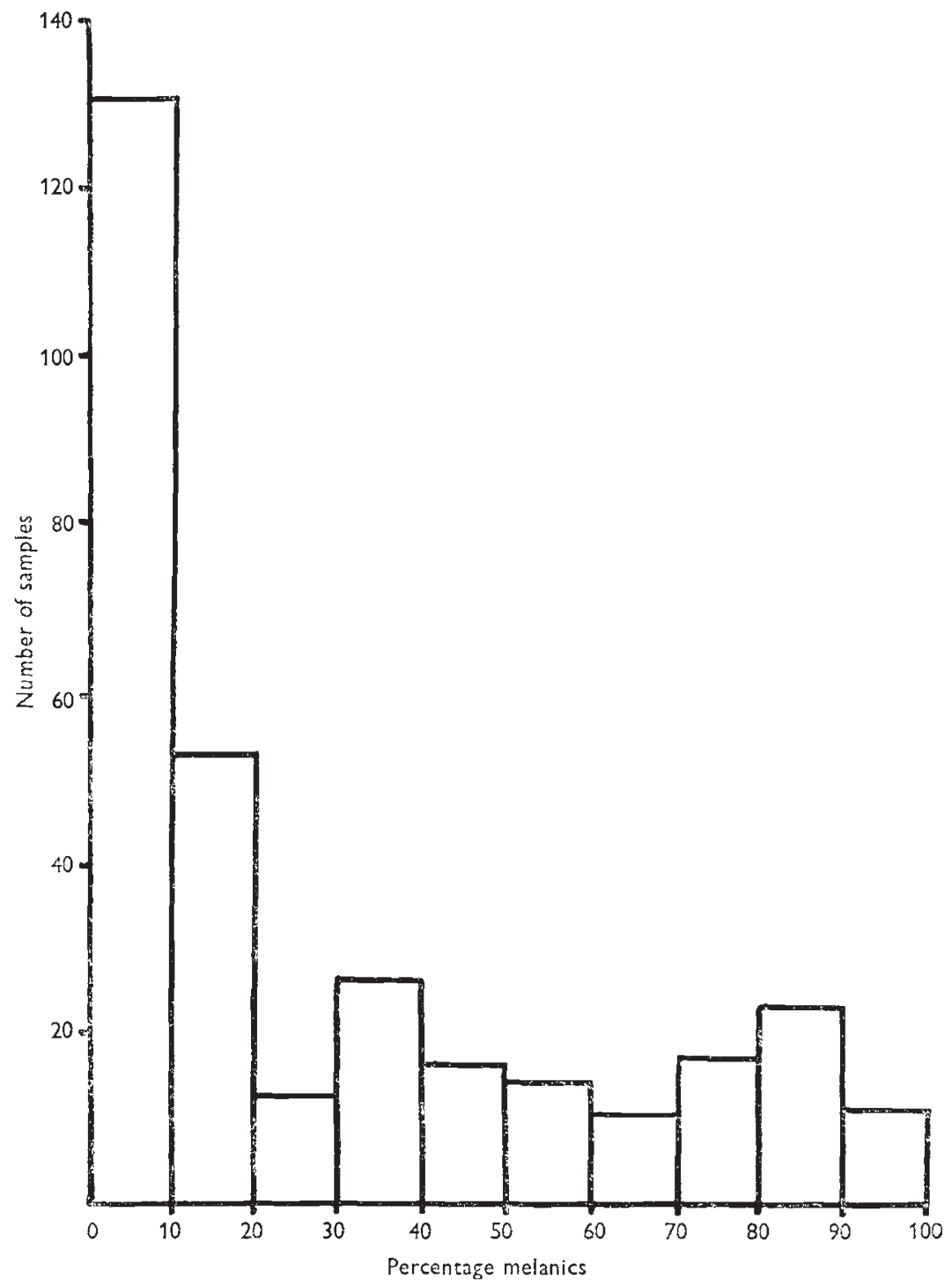

FIG. 1. - The percentage of the melanic morphs of Adalia bipunctata in 321 samples from Europe and Asia. Data from published sources mentioned in the text.

result of intense selection against the melanic morphs. Knowledge of the selective disadvantage of the melanics is essential to our understanding of this polymorphism. In this paper I shall review the work on this subject and suggest some additional factors which may be involved. 


\section{The nature of the disadvantage of the melanic morphs}

\section{(i) Selection during the winter}

Timoféeff-Ressovsky (1940), working in Berlin, found significant changes in morph frequency between spring and autumn, with the non-melanic being the commoner morphs in the spring and the melanics being the commoner morphs in the autumn. By examining hibernating ladybirds he was able to show that mortality of melanics during the winter was greater than that of the non-melanics. In the course of the summer melanic frequencies increased. Timoféeff-Ressovsky concluded that these seasonal variations in morph frequency were the result of selection taking place in opposite directions in winter and summer. More recently TimoféeffRessovsky and Svirezhev $(1966,1967)$ have re-analysed these results and suggested that the balance between the two opposing selective factors could in itself maintain the polymorphism. They have termed this "adaptive polymorphism " to distinguish it from polymorphism maintained by heterozygote advantage. This suggestion has been challenged by Creed (1975) who claims that their model does not result in a stable equilibrium and that heterozygote advantage must be present at some stage. On the other hand, Haldane and Jayakar (1963) point out that a polymorphism can be maintained by selection in opposite directions in a situation where the opposing selective forces are large, and Hedrick (1973) has shown that, in a situation analagous to that of $A$. bipunctata in Berlin, cyclic environmental variation can maintain a stable polymorphism.

Lusis (1961) suggested that the greater changes in body temperature experienced by the melanic morphs as a result of their more rapid heating and cooling may account for the winter mortality found by TimoféeffRessovsky. Other authors have also suggested that temperature may play a part in selecting against melanics during the winter (Creed, 1975; Scali and Creed, 1975). Creed (1975) has found a non-significant correlation between lowest mean monthly temperature in winter and selection against melanics in Berlin, but he points out that length of winter may be an important factor. Scali and Creed (1975) have found a positive correlation between melanic frequency and altitude in Northern Italy and have suggested that this is related to the colder temperatures at higher altitudes. Data given by Lusis (1973) suggests that a similar relationship may occur in some parts of Central Asia. Scali and Creed (1975) also found a positive correlation between mean annual temperature and melanic frequency, but they point out that this relationship does not apply throughout the range of $A$. bipunctata. Indeed, in Great Britain there is a significant negative correlation between melanic frequency and mean winter temperature $(r=0.508, n=32)$ although this may be related to the correlation between mean winter temperature and annual sunshine hours at the same sites $(r=0 \cdot 662, n=32)$. In Great Britain sunshine levels appear to be one of the major factors determining morph frequency (Muggleton et al., 1975).

The extent to which cyclical changes in morph frequency occur elsewhere than in Berlin is not known. Both Hawkes (1920) and Marriner (1926) remarked that the non-melanic morphs were commoner earlier in the season at the localities in England where they made their observations, but from their data it is not possible to tell whether this was due to increased mortality of melanics during the winter. Data collected by Creed (1975) 
in Birmingham between 1962 and 1970 show neither significant differences in morph frequencies between samples nor any uniform trend, although this may be because the time between early and late samples was short. Table 1 shows the melanic frequencies at six sites I have sampled in spring and late summer for two or more consecutive years. At all these sites there are nonsignificant changes in melanic frequency between samples and taken

\section{TABLE 1}

Melanic frequencies in the earliest and latest samples collected at six sites in southern England. In each case the animals sampled in late summer are the offspring of those sampled in the spring.

\begin{tabular}{|c|c|c|c|c|}
\hline \multirow[b]{2}{*}{ Locality } & \multirow[b]{2}{*}{ Date } & \multicolumn{2}{|c|}{ Numbers } & \multirow[b]{2}{*}{$\%$ melanics } \\
\hline & & Non-melanics & Melanics & \\
\hline Avonmouth & $\begin{array}{rll}7 & \text { May } 1976 \\
7 & \text { Sept } 1976 \\
2 & \text { June } 1977 \\
10 & \text { Sept } 1977\end{array}$ & $\begin{array}{r}102 \\
102 \\
82 \\
41\end{array}$ & $\begin{array}{r}12 \\
6 \\
8 \\
3\end{array}$ & $\begin{array}{r}10 \cdot 5 \\
5 \cdot 6 \\
8 \cdot 8 \\
6 \cdot 8\end{array}$ \\
\hline Cheltenham & $\begin{array}{r}6 \text { May } 1976 \\
17 \text { Sept } 1976 \\
1 \text { June } 1977 \\
11 \text { Sept } 1977\end{array}$ & $\begin{array}{l}47 \\
47 \\
57 \\
50\end{array}$ & $\begin{array}{l}2 \\
2 \\
0 \\
1\end{array}$ & $\begin{array}{l}4 \cdot 1 \\
4 \cdot 1 \\
0 \\
2 \cdot 0\end{array}$ \\
\hline Gloucester & $\begin{array}{rll}6 & \text { May } & 1976 \\
6 & \text { Sept } & 1976 \\
19 & \text { May } & 1977 \\
10 & \text { Sept } 1977\end{array}$ & $\begin{array}{r}118 \\
49 \\
32 \\
64\end{array}$ & $\begin{array}{r}18 \\
10 \\
1 \\
8\end{array}$ & $\begin{array}{r}13 \cdot 2 \\
17 \cdot 0 \\
3 \cdot 0 \\
11 \cdot 1\end{array}$ \\
\hline Nottingham & $\begin{array}{rll}19-30 \text { May } & 1976 * \\
21-30 \text { Sept } 1976 * \\
25 \text { May } 1977 \\
26 \text { Aug } 1977\end{array}$ & $\begin{array}{r}320 \\
161 \\
104 \\
42\end{array}$ & $\begin{array}{l}8 \\
4 \\
2 \\
1\end{array}$ & $\begin{array}{l}2 \cdot 4 \\
2 \cdot 4 \\
1 \cdot 9 \\
2 \cdot 3\end{array}$ \\
\hline Staines (a) & $\begin{array}{l}26 \text { April } 1975 \\
13 \text { Sept } 1975 \\
16 \text { April } 1976 \\
12 \text { Sept } 1976 \\
12 \text { April } 1977 \\
20 \text { Aug } 1977\end{array}$ & $\begin{array}{l}42 \\
40 \\
27 \\
29 \\
19 \\
31\end{array}$ & $\begin{array}{l}4 \\
2 \\
3 \\
4 \\
1 \\
3\end{array}$ & $\begin{array}{r}8 \cdot 7 \\
4 \cdot 8 \\
10 \cdot 0 \\
12 \cdot 1 \\
5 \cdot 0 \\
9 \cdot 7\end{array}$ \\
\hline Staines (b) & $\begin{array}{lll}15 & \text { May } & 1976 \\
19 & \text { Sept } & 1976 \\
13 & \text { May } & 1977 \\
21 & \text { Aug } & 1977\end{array}$ & $\begin{array}{r}208 \\
23 \\
50 \\
70\end{array}$ & $\begin{array}{r}12 \\
0 \\
6 \\
2\end{array}$ & $\begin{array}{c}5 \cdot 5 \\
0 \\
10 \cdot 7 \\
2 \cdot 8\end{array}$ \\
\hline
\end{tabular}

* Animals marked in the course of mark-recapture experiments.

together there is no evidence of a uniform trend. At only one locality, Gloucester, is the pattern consistent with the changes observed in Berlin. Samples collected in the U.S.S.R. (Lusis, 1973), Czechoslovakia (Honek, 1975) and Norway (Bengston and Hagen, 1975) also show no significant differences or trends. It is, of course, possible that Berlin is one of the few places where the balance between summer and winter selection results in a polymorphism and that in other localities selection by one or other factor results in a population containing a majority of one morph. If this is true, then localities in Great Britain with high frequencies of non-melanics should show correspondingly high selection against melanics during the winter. 
That this cannot be found suggests that selection against melanics in Great Britain may be taking place in another season.

\section{(ii) Selection during the summer}

Muggleton et al. (1975) suggested that the greater heat absorption and activity of the melanic morphs would put them at a disadvantage during the summer months as a result of overheating and desiccation and Hodek (1973) points out that for many polymorphic ladybirds there is a tendency for increases in melanic frequency to be associated with increasing humidity. The relationship between high melanic frequencies in $A$. bipunctata and high humidity has been stressed by Lusis (1961) and, more recently, by Bengston and Hagen (1977). The existence, however, of high melanic frequencies in areas where sunshine levels and temperatures are considerably in excess of those in north-western Europe (e.g. northern Italy, the Crimea and in hot and dry regions of central Asia) suggests that melanics are able to tolerate conditions of high temperature and low humidity. Additional support for this suggestion comes from the findings of Hawkes (1920) and Marriner (1926) that in captivity the melanics can withstand high temperature better than the non-melanics. The possibility cannot be ignored, however, that the genetic constitution of the melanics differs from place to place or that local adaptations may have occurred. The former may certainly be true of the Central Asian populations where the majority of the melanics are of the form sublunata which is uncommon in Europe; other morphological and genetic differences have led Lusis (1973) to consider these Central Asian populations as a subspecies of $A$. bipunctata.

\section{(iii) Generation time}

In Berlin the increase in melanics took place during the course of three successive generations in the summer (Timoféeff-Ressovsky and Svirezhev, 1966), and it may be supposed that the frequency of melanics increases from generation to generation. In localities where there were fewer generations a year the increase in melanics during the summer would not be so great unless the selective advantage per generation was larger. Table 2 shows

TABLE 2

Percentage of A. bipunctata found copulating in samples from southern and eastern England during 1976. (1) and (2) indicate the first and second halves of the month

$\begin{array}{lcc} & \begin{array}{c}\% \\ \text { in cop. }\end{array} & \begin{array}{c}\text { Sample } \\ \text { size }\end{array} \\ \text { April } & 11 \cdot 5 & 192 \\ \text { May (1) } & 22 \cdot 4 & 1640 \\ \text { May (2) } & 24 \cdot 7 & 1246 \\ \text { June (1) } & 17 \cdot 5 & 620 \\ \text { June (2) } & 10 \cdot 4 & 308 \\ \text { July } & 0 & 1261 \\ \text { August } & 0 & 111 \\ \text { September } & 0 & 588\end{array}$


the percentage of mating pairs found in samples collected in southern and eastern England between April and September 1976. These data indicate that there was only one period of mating activity and hence only one generation in this long, hot summer. Data collected from Kew, in southern England, between 1964 and 1968, confirm this finding (Eastop and Pope, 1969). Klausnitzer (1971) states that in central Europe A. bipunctata has at most two generations a year and in Norway there is only one generation (Ellingsen, 1969). If $A$. bipunctata is a univoltine species in England the ability of the melanics to increase during the summer months will be much reduced and one of the advantages of the melanic morphs will be largely eliminated.

\section{(iv) Migration}

Creed (1966, 1971a) has proposed that melanic frequencies may be low in certain isolated industrial towns because the selective advantage of the melanics in these localities is counteracted by gene flow from the surrounding non-melanic populations. In order to demonstrate this it would be necessary to know the level of the selective advantage of the melanics and the migration rate for specific localities. While such information is not available, it is possible to come to some general conclusions about migration rates. Data collected in the course of four mark-recapture experiments (Muggleton, in preparation) show that over periods of several weeks movement of more than a few metres are rare. Although reports of ladybird migrations are common, in Great Britain at least, A. bipunctata is rarely involved (Muggleton and Benham, in preparation). The picture of $A$. bipunctata as a rather immobile species is reinforced by the steep clines in morph frequency which are invariably associated with areas of high melanic frequency (Creed, 1971 $a$; Muggleton, unpublished). Similar clines are associated with the melanic polymorphism of the moth Gonodontis bidentata and have been ascribed to the low migration rates of this species (Bishop and Cook, 1975). Indeed, comparing the pattern of melanism of $A$. bipunctata in the industrial northwest of England with that of melanism in both $G$. bidentata and Biston betularia it is apparent that the pattern is much more like that of the less mobile $G$. bidentata than of the much more mobile $B$. betularia (Bishop et al., 1978a). Thus it is probable that at least in areas of high melanic frequency a lack of migration is reducing the spread of the melanic morphs. This, in turn, suggests that the existence of low melanic frequencies in isolated industrial towns cannot be explained in terms of migration and that an explanation for it must be sought elsewhere (see Muggleton et al., 1975).

\section{(v) Selective predation}

In contrast to the other melanic polymorphisms in invertebrates, the possibility that selective predation is a factor maintaining the polymorphism in $A$. bipunctata has been ignored on the assumption that ladybirds are aposematic and avoided by vertebrate predators. This assumption has arisen as the result of experiments in which birds and other vertebrates have been offered ladybirds as food in laboratory experiments. While the early experiments of this kind were often inconclusive (Pocock, 1911; McAtee, 1912; Heikertinger, 1932) the more recent work of Frazer and 
Rothschild (1960) showed that when ladybirds, including $A$. bipunctata, were offered to a variety of vertebrates they were invariably rejected as food. However, these results conflict with the many reports of predation on ladybirds by birds and other vertebrates (Heikertinger, 1932; Hodek, 1973; Klausnitzer, 1971). I have located records of 19 species of birds which have been found to reject ladybirds as food in laboratory experiments, whereas there are published records of 121 bird species having eaten ladybirds, mostly in natural conditions, and these include six of the species found to reject ladybirds in laboratory conditions. Heikertinger (1932) was able to list some 40 European birds, most of which occur in Great Britain, as having been recorded as eating ladybirds, or having ladybirds found in their stomachs or droppings. My own examination of $38 \mathrm{gm}$ of dried House Martin (Delichon urbica) droppings collected from under a nest in Northenden, Manchester, by M. V. Hounsome in 1976 showed them to consist almost entirely of the remains of five species of ladybird (Adalia bipunctata, A. 10punctata, Coccinella 7-punctata, C. 11-punctata and Propylea 14-punctata). In spite of being fed on ladybirds the young were reared successfully.

TABLE 3

Numbers of previously frozen melanic and non-melanic A. bipunctata taken during predation experiments

\begin{tabular}{|c|c|c|c|c|c|}
\hline \multirow[b]{2}{*}{ Locality } & \multicolumn{2}{|c|}{ Numbers taken } & \multicolumn{2}{|c|}{ Numbers left } & \multirow{2}{*}{$\begin{array}{c}\text { Relative } \\
\text { survival } \\
\text { of melanics }\end{array}$} \\
\hline & Non-melanic & Melanic & Non-melanic & Melanic & \\
\hline $\begin{array}{c}\text { Woodchester Park, } \\
\text { Glos., July } 1975\end{array}$ & 1 & 3 & 49 & 47 & 0.96 \\
\hline $\begin{array}{l}\text { Nottingham, } \\
\text { July-August } 1976\end{array}$ & 12 & 16 & 39 & 35 & 0.9 \\
\hline $\begin{array}{l}\text { Chobham Common } \\
\text { Surrey, Oct-Nov } 1976\end{array}$ & 3 & 6 & 27 & 24 & 0.89 \\
\hline $\begin{array}{l}\text { Nottingham, } \\
\text { June } 1977\end{array}$ & 7 & 7 & 18 & 18 & 1.0 \\
\hline
\end{tabular}

In view of the quite different situations experienced by birds in experimental and natural surroundings this conflict of results is not surprising. For example, the reaction of a caged well-fed bird used to a limited number of prey species is unlikely to be the same as that of its wild counterpart, which may not only be hungry but may also be faced with a large number of prey species in a short time, of which only a few are distasteful. Under these conditions it seems inevitable that the experimental birds will avoid ladybirds more readily. Thus laboratory experiments have only a limited value, which is to identify species that are potentially distasteful. The extent to which this distastefulness is a deterrent to predation under natural conditions can only be determined by observation of wild animals. Undoubtedly, ladybirds are distasteful and warningly coloured, but there can be little doubt that the results obtained by Frazer and Rothschild (1960) are misleading to the extent that they imply a far greater protection of ladybirds by their scent and colour than actually exists.

A selective predation experiment, carried out in July and August 1976 in Nottingham, during which frozen ladybirds were glued to the twigs of apple trees in life-like positions in the same manner as has been used for 
selective predation experiments with the moths Biston betularia and Gonodontis bidentata (Bishop, 1972; Bishop, Cook and Muggleton, 1978b) showed that 28 per cent of the ladybirds were taken $(n=102)$ and that the relative survival of melanics compared to typicals was 0.9 . An experiment using the same trees in June 1977 showed the same predation rate but on this occasion equal numbers of melanics and non-melanics were taken $(n=50)$. An experiment done on pine trees on Chobham Common, Surrey, showed 15 per cent predation $(n=60)$ and a relative survival rate for the melanics of 0.89 . A further experiment, again on apple trees, but this time at Woodchester Park in Gloucestershire, was carried out by Papeeta Mackenzie and Judith Prince as part of a field course project and on this occasion the predation rate was only 4 per cent $(n=100)$. Mackenzie and Prince believed their low predation to have been the result of the specimens thawing before the experiment and thus becoming unpalatable. In the other experiments the ladybirds retained their distinctive scent for the 24-hour period during which they were exposed to predation. These experiments show that ladybirds (at least our frozen specimens, which are not known to be perceived by birds differently from live ones) are taken more readily by birds than would have been expected from the observations of Frazer and Rothschild on live ladybirds (1960). Indeed, the predation rates are not far removed from those found in the selective predation experiments mentioned above, using moths which are cryptic and palatable. The average predation rate in these experiments with moths was 33 per cent and ranged from 18 to 50 per cent.

Fifty-one fragments of $A$. bipunctata, each large enough to have come from a single ladybird, were recovered from the House Martin droppings mentioned above. Of the 26 left elytra, 20 were from melanics and of the 25 right elytra, 24 were from melanics. The mean melanic frequency from left and right elytra is 86.3 per cent which does not differ significantly from the expected melanic frequency for the Northenden area (Bishop et al., 1978a). Thus the House Martins appeared to have taken the morphs randomly, but this may not be surprising for a bird which captures its prey on the wing.

Nevertheless, although their protection is imperfect, it is hard to escape the conclusion that ladybirds do form an assemblage of Müllerian mimics. For while polymorphism is common amongst the Coccinellidae, the majority of species are red with black spots and they share the same distinctive scent (Rothschild, 1961). Given this fact and the existence of predation it may well be that the scarcer melanics are not recognised as ladybirds in the majority of situations where red species will predominate. It is interesting to note that in Great Britain there are some species of ladybird which are always black with red spots. The commonest of these is Exochomus quadripustulatus which is very similar in size and colour pattern to the quadrimaculata morph of $A$. bipunctata. This species is associated with pine trees and in such habitats can be one of the commonest ladybirds. It may be that in such areas the melanic morphs of $A$. bipunctata will be better protected against predation as predators will be accustomed to finding black ladybirds, and this may explain the unexpectedly high frequencies of melanism in $A$. bipunctata found by Creed (1966) to the south-west of London where pine and E. quadripustulatus are particularly abundant. Edmunds (1974) has suggested that the melanic morphs of $A$. bipunctata may be cryptic against certain backgrounds 
and the dark bark of pine trees certainly offers a background against which melanic ladybirds are difficult to see. A. bipunctata, however, rarely occurs on pine trees and the selective predation experiment carried out on pine trees on Chobham Common shows a disadvantage to the melanic morphs.

\section{Discussion}

At present there seems to be no factor which can be positively identified as selecting against the melanic morphs. While the results from Berlin indicate that selection there is taking place during the winter, these results do not appear to be repeated elsewhere, although given the wide range of climates experienced by the species this may not be surprising. If, however, selection against the melanic morphs during the winter is general, then the existence of a univoltine life cycle in many regions may have prevented the build-up of melanics in areas where the advantage to them during the remainder of the year is marginal.

The similarity of the predation rates on moths and ladybirds in predation experiments suggests that both cryptic and aposematic coloration can offer similar levels of protection from vertebrate predators. That avian predation on ladybirds can be considerable must now be accepted and suggests that in some areas selective predation could be involved in the polymorphism of A. bipunctata. In a similar way Kettlewell's finding (Kettlewell, 1956), against the opinion of the day, that $B$. betularia on tree trunks were commonly eaten by birds led to the elucidation of the polymorphism in that species.

Throughout this paper no attention has been given to the fact that there are several melanic morphs of $A$. bipunctata, two of which are common in Great Britain, and this reflects the habit of previous authors of placing all the melanic morphs in one category. From the little that is known of the distribution of the melanic morphs it appears that their proportions in samples vary geographically and it is probable that these different melanic morphs are responding differently to some of the selective factors. Such a difference in response would add to the difficulty of analysing the polymorphism and future work should indicate which melanic morphs are concerned.

In conclusion, it is evident that the factors selecting against melanics are not the same throughout the range of the species. That a number of selective factors may be acting on the polymorphism should not be surprising, indeed this may be true for most of the widespread polymorphsims which have been studied. The literature on Cepaea nemoralis contains many accounts indicating the nature of selective agents in particular areas (Cain and Sheppard, 1954; Lamotte, 1959; Arnold, 1968; Jones, 1973) which often conflict with the findings from other parts of the species' range. The same is true for the spittlebug Philaenus spumarius where selective predation by birds, climate, parasites and effects of air pollution (Owen and Wiegert, 1962; Halkka, Raatikainen and Vilbaste, 1975; Harper and Whittaker, 1976; Creed, pers. comm.) have all been suggested as selective agents. These examples all refer to colour polymorphisms, but the same multiplicity of selective factors has also been proposed for some enzyme polymorphisms. Latitude, substrate, temperature, and frequency dependent selection have all been suggested at the alcohol dehydrogenase locus of Drosophila melanogaster (Vigue and Johnson, 1973; Pipkin, Rhoades and Williams, 1973; Morgan, 1975; Kojima and Tobari, 1969). 
There has, however, been a tendency to overlook the possible complexity of selective factors and to search instead for some single factor which will explain the entire picture. Such an approach leads to difficulties in explaining why similar morph frequencies are found in widely differing habitats or localities. Thus the fact that a particular selective factor does not seem to be important in one locality has been taken as evidence that nowhere else is it important (e.g. the climatic selection $v$. selective predation controversy in Cepaea nemoralis). This type of argument has been applied to the polymorphism in $A$. bipunctata by Scali and Creed (1975) who compare the situation in central Italy to that in Great Britain. Such difficulties are avoided if the polymorphism is considered as being the result of the interaction of a number of selective factors whose relative importance may differ from one locality to another. This argument may be applied to the polymorphism in $A$. bipunctata. It is probable that throughout the range of the species the melanic morphs of $A$. bipunctata have an advantage over nonmelanics in terms of their more efficient absorption of solar radiation (Lusis, 1961; Muggleton et al., 1975). Over much of the range, however, this advantage may be counteracted by varying combinations of other factors including winter mortality, selective predation, number of generations per year, migration rate and perhaps a disadvantage of melanic homozygotes. High melanic frequencies may occur in high, as well as low, sunshine areas. In high sunshine areas the melanic frequency will depend on the extent to which selection against melanics counteracts their thermal advantage. In low sunshine areas it is probable that their thermal advantage will always be in excess of the disadvantages.

Acknowledgements.-I should like to thank Brian Benham for his useful comments during many discussions on this subject. Drs L. M. Cook, T. H. Day and D. T. Parkin kindly read and commented on drafts of this paper. I am grateful to $\mathrm{Mr}$ A. R. Kelly for providing facilities at Woodchester Park and to Dr M. V. Hounsome for collecting the House Martin. droppings. This work was done while the author was in receipt of an S.R.C. Studentship.

\section{REFERENGES}

ARnold, R. W. 1968. Studies on Cepaea VIII. Climatic selection in Cepaea nemoralis (L) in the Pyrenees. Phil. Trans. R. Soc. Lond. B, 253, 549-593.

Bengston, s-A., AND hagen, R. 1975. Polymorphism in the two-spot ladybird Adalia bipunctata in Western Norway. Oikos, 26, 328-331.

Bengston, s-A., AND HAGEN, R. 1977. Melanism in the two-spot ladybird Adalia bipunctata in relation to climate in western Norway. Oikos, 28, 16-19.

BISHOP, J. A. 1972. An experimental study of the cline of industrial melanism in Biston betularia (L.) (Lepidoptera) between urban Liverpool and rural North Wales. F. anim. Ecol., 41, 209-243.

Brshop, J. A., AND Cook, L. M. 1975. Moths, melanism and clean air. Sci. Amer., 232 (1), 90-99.

BISHOP, J. A., COOK, L. M., AND MUGGLETON, J. 1978a. The response of two species of moths. to industrialisation in north west England. I. Polymorphism for melanism. Phil. Trans. R. Soc. Lond. B 281, 489-515.

BISHOP, J. A., COOK, L. M., AND MUGGLETON, J. 1978b. The response of two species of moths. to industrialisation in north west England. II. Relative fitness of morphs and population sizes. Phil. Trans. R. Soc. Lond. B 281, 517-540.

Cain, A. J., AND sheppard, P. M. 1954. Natural selection in Cepaea. Genetics, 39, 89-116. CREED, E. R. 1966. Geographic variation in the two-spot ladybird in England and Wales. Heredity, 21, 57-72. 
CREED, E. R. $1971 a$. Melanism in the two-spot ladybird, Adalia bipunctata, in Great Britain. In Ecological Genetics and Evolution, ed. E. R. Creed, pp. 134-151. Blackwell Scientific Publications, Oxford.

CREED, E. R. $1971 \mathrm{~b}$. Industrial melanism in the two-spot ladybird and smoke abatement. Evolution, 25, 290-293.

GREED, E. R. 1975. Melanism in the two-spot ladybird: the nature and intensity of selection. Proc. R. Soc. Lond. B, 190, 135-148.

EASTOP, V. F., AND POPE, R. D. 1969. Notes on the biology of some British Coccinellidae. Entomologist, 102, 162-164.

edmunds, M. 1974. Defence in animals: a Survey of Anti-predator Defences. Longman, Harlow.

ELlingsen, I-J. 1969. Fecundity, Aphid consumption and survival of the aphid predator Adalia bipunctata L. (Col., Coccinellidae). Norsk. ent. Tidsskr., 16, 91-95.

FRAZER, J. F. D., AND ROTHSCHILD, M. 1960. Defence mechanisms in warningly-coloured moths and other insects. Proc. 11th Int. Cong. Entomology, 3, 249-256.

haldane, J. B. S., AND JAYAKaR, s. D. 1963. Polymorphism due to selection of varying direction. F. Heredity, 58, 237-242.

halkKa, O., RAATIKaINEN, M., AND vilBaste, J., 1975. Clines in the colour polymorphism of Philaenus spumaris in Eastern Central Europe. Heredity, 35, 303-309.

hammond, Р. м. 1975. Seventeenth century British Coleoptera from the collection of Leonard Plukenet (1642-1706). Ent. Gazette, 26, 261-268.

HARPER, G., AND WHITTAKER, J. B. 1976. The role of natural enemies in the colour polymorphism of Philaenus spumaris (L.). 7. Anim. Ecol., 45, 91-104.

HAWKEs, O. A. M. 1920. Observations on the life-history, biology and genetics of the ladybird beetle, Adalia bipunctata (Mulsant). Proc. zool. Soc. Lond., 1920, 475-490.

HEDRICK, P. W. 1973. Genetic variation in a heterogeneous environment. I. Temporal heterogeneity and the absolute dominance model. Genetics, 78, 757-770.

HEIKERTINGER, F. 1932. Die Coccinelliden, ihr "Ekelblut", ihre Warntracht und ihre Feinde. II. Teil. Die Feinde der Coccinelliden. Biol. Zbl., 52, 385-412.

HODEK, I. 1973. Biology of Coctinellidae. Academia, Prague.

HONEK, A. 1975. Colour polymorphism in Adalia bipunctata in Bohemia (Coleoptera : Coccinellidae). Ent. Germ., 1, 293-299.

JONEs, J. s. 1973. Ecological genetics of a population of the snail Cepaea nemoralis at the northern limit of its range. Heredity, 31, 201-211.

KETTLEWELL, H. B. D. 1956. Further selection experiments on industrial melanism in the Lepidoptera. Heredity, 10, 287-301.

KLAussitzer, B. 1971. Zur Biologie einheimischer Käferfamilien. 8. Coccinellidae. Ent. Ber., 1971, 86-97.

KOJIMA, K-I., AND tOBARI, Y. N. 1969. The pattern of viability changes associated with genotype frequency at the alcohol dehydrogenase locus in a population of Drosophila melanogaster. Genetics, 61, 201-209.

LAмотте, м. 1959. Polymorphism of natural populations of Cepaea nemoralis. Cold Spring Harb. Symp. quant. Biol., 24, 65-84.

LUs, J. J. (LusIs). 1928. On inheritance of colour and pattern in ladybeetles Adalia bipunctata and Adalia decimpunctata. Izv. Byuro. Genet. Leningrad, 6, 89-163.

LUs, J. J. (Lusss). 1932. An analysis of the dominance phenomenon in the inheritance of the elytra and pronotum colour in Adalia bipunctata. Trudy Lab. Genet., 9, 135-162.

Lusis, J. J. 1961. On the biological meaning of colour polymorphism of ladybeetle Adalia bipunctata L. Latv. Ent., 4, 3-29.

LUsIs, J. J. 1973. Taxonomical relationships and geographical distribution of forms in the ladybird genus Adalia Mulsant. Uch. Zap. latvijskogo gosud. Univ. im Petra Stutchki (Riga), 184, 5-127.

MCATEE, w. L. 1912. The experimental method of testing the efficiency of warning and cryptic coloration in protecting animals from their enemies. Proc. Acad. Nat. Sci. Philad., 64, 281-364.

MARRINER, T. F. 1926. A hybrid coccinellid. Entomologist's Rec. F. Var., 38, 81-83.

MORGAN, P. 1975. Selection acting directly on an enzyme polymorphism. Heredity, 34, 124-127.

MUgGleton, J., LONSDALE, D., AND BENham, B. R. 1975. Melanism in Adalia bipunctata L. (Col., Coccinellidae) and its relationship to atmospheric pollution. F. appl. Ecol., $12,451-464$.

OWEN, D. F., AND WIEGERT, R. G. 1962. Balanced polymorphism in the meadow spittlebug, Philaenus spumaris. Amer. Naturalist, 96, 353-359. 
PIPKIN, s. B., RHOADEs, C., AND WILliAMS, N. 1973. Influence of temperature on Drosophila alcohol dehydrogenase polymorphism. F. Hered., 64, 181-185.

Pocock, R. J. 1911. On the palatability of some British insects, with notes on the significance of mimetic resemblances. With notes on the experiments by E. B. Poulton. Proc. Zoo. Soc. Lond., 1911.

ROTHSCHIL, M. 1961. Defensive odours and Müllerian mimicry among insects. Trans. R. ent. Soc. Lond., 113, 101-109.

SCALI, V., AND CREED, E. R. 1975. The influence of climate on melanism in the two-spot ladybird, Adalia bipunctata, in central Italy. Trans. R. ent. Soc. Lond., 127, 163-169.

TIMOFEEFF-REssovsky, N. w. 1940. Zur Analyse des Polymorphismus bei Adalia bipunctata L. Biol. Zbl., 60, 130-137.

TIMOFÉEFF-RESSOVSKY, N. W., AND SVIREZHEV, YU. M. 1966. Adaptation polymorphism in populations of Adalia bipunctata L. Problemy Kibern., 16, 137-146 (English translation: Probl. Cybern., 16, 161-174.)

TIMOFÉEFF-RESSOVSKY, N. W., AND SVIREZHEV, YU. M. 1967. Genetic polymorphism in populations: an experimental and theoretical investigation. Genetika (Moscow), 3, 152-166 (English translation: Soviet Genetics, 3, 82-89.)

VIGUE, C. L., AND Johnson, F. M. 1973. Isozyme variability in species of the genus Drosophila. VI. Frequency-property-environment relationshisp of allelic alcohol dehydrogenases in Drosophila melanogaster. Biochem. Genet., 9, 213-227. 